ISSN: $2036-5438$

\title{
Eurosceptic Federalism: Paradoxes and Relevance of a long-running Critique of European Integration
}

by

\author{
Tommaso Visone*
}

Perspectives on Federalism, Vol. 10, issue 1, 2018 


\begin{abstract}
In recent political debate, the association between national souverainisme and Euroscepticism is considered a natural one. From Marine Le Pen to Matteo Salvini, there is a unanimous affirmation of the necessity to defend national sovereignty against the threat of Brussels. But if we take a more in-depth look, we can see how European Integration has fed two different approaches to European federalism: the first began in 1951, a concrete path on which a kind of European federation was progressively built, while the second has considered the same path to be an obstacle in the attempt to move towards a possible European federation. According to the first group the process of integration has been better than nothing while, the opinion of the second is that the same process has been worse than nothing. Such Eurosceptic Federalism finds its roots in the anti-cosmopolitan federalism of the interwar debate and unifies, paradoxically, radical libertarians and convinced communitarians.
\end{abstract}

\title{
Key-words
}

Euroscepticism, federalism, European integration, Alain de Benoist, Gianfranco Miglio 
The recent political debate presents the association between anti-federalist nationalism and Euroscepticism ${ }^{\mathrm{I}}$ as the ideological core of the Anti-EU discourse. From Marine Le Pen to Nigel Farage, and Geert Wilders and Matteo Salvini, there is a unanimous affirmation of the necessity to defend national sovereignty against the threat posed by Brussels bureaucracy and institutions. A good example is this quote by Marine le Pen who considered "L'Europe de Bruxelles" as a "Super-Etat eurocratique" that ruins the lives of millions of Europeans. In her view, France must "renégocier les traités" in order to "mettre fin à l'asservissement de la France, de restaurer notre souveraineté nationale dans l'ensemble des domaines où elle a disparu, de nous rendre le pouvoir". A "ministère des Souverainetés" would be in charge "pour restaurer la souveraineté nationale dans l'ensemble des domaines où elle a disparu". II In this case, it is evident that the choice to fight for national sovereignty brings this kind of Eurosceptic discourse to the antipodes of any possible kind of "European federalism". "III But a more indepth examination - below the surface of daily national struggles and rhetoric - will reveal that the history of European Integration has been intertwined with two different approaches to European federalism: the first - present in the Schuman declaration itself ${ }^{\mathrm{IV}}-$ has its foundations in the process begun in 1951, a concrete path on which a kind of European federation was progressively built, ${ }^{\mathrm{V}}$ while the second - present in different and heterogeneous political movements ${ }^{\mathrm{VI}}$ - considered the same path to be an obstacle in its attempt to move towards a possible European federation. According to the first group the process of integration has been better than nothing while, in the view of the second, the same process has been worse than nothing, because it prevented the realisation of an authentic European federation. With reference to this second group, it is possible to speak about an authentic "Eurosceptic European Federalism".

1.

Considering the juncture of such a paper, I would like to give a glimpse of the history of such an approach, in order to briefly pass onto a couple of interesting case studies. The idea of avoiding functional and international integration or governance in order to preserve the possibility of true European federalism found its roots in the critique of cosmopolitan and international projects of liberal democracies elaborated, in the context of the Thirties, 
by different intellectuals such as Pierre Drieu La Rochelle, Eugeni d'Ors, and the Ordre Nouveau group among others. In the Thirties, after showing interest in the Briand Plan for European Federation, Pierre Drieu La Rochelle considered capitalism to be close to death and hoped to see a new Fascist League of Nations, "une Genève des fascisms", that would substitute the existing one, incapable of stopping the European path towards a new war. ${ }^{\text {VII }}$ From his point of view only fascism could federate Europe, realising that a "European Union", where capitalist democracies failed, and the creation a League of Nations, were just too exposed to national interests to create a true economic federation. ${ }^{\text {VIII }}$ For him, Nazi Germany, by abolishing the national frontier, had worked in its creation of the only possible path towards the federal reunification of Europe (moreover also granting it a new organising principle - spiritual and racial) (Drieu la Rochelle 1973: 188-190; Visone 2014: 134-141). Also fascinated by fascism - although more so by the Italian version (Visone 2015: 342-343) - Eugeni D'Ors criticised the Liberal Europe of the SND and the Communist International, hoping to realise a true federal-corporative Europe. He saw this as synonymous with an "empire", or a unity capable of putting together various levels of government in a supranational and multinational space - able to join nations, regions, cultures without destroying their differences (Martínez Carrasco 2014: 72). This was seen in direct contraposition with the cosmopolitanism of liberal organisations that just melt and liquefy nations and diversities (D'Ors 1920: 1). Or we can consider the case of the ninistes proudhonian federalists who wrote for the "Ordre Nouveau" review and considered it impossible to proceed with projects such as the Paneurope of Coudenhove Kalergi, and the League of Nations, that continued to have at their centre the nation-state. As written by Alexandre Marc, it was vain and useless to proceed with these projects because their will just masked the horrible reality of the nation-state. Thus, it was necessary to promote something else, such as a federation of communities that started at the local level and aimed to reach the people (Glady 1934: 8-20). ${ }^{\text {IX }}$ In any case, these criticisms of liberal internationalism and federalism were directed towards contesting the enduring role of the nation-state within and the cultural (and racial, according to Drieu La Rochelle) homologation created by such liberal universalism. These ideas would go on to play an important role in criticism aimed at the process of European integration during the second half of the $\mathrm{XX}^{\text {th }}$ century. 
2.

After the second world war, different radical criticisms were directed towards the process of European integration from a federalist perspective. One in particular, that of ethno-federalism, had a political relevance. According to one of its main theorists, the French jurist Guy Héraud, ${ }^{\mathrm{X}}$ the idea of proceeding towards a confederation of states following the functionalist approach is a form of "right wing deviationism" that did not solve the issue of nationalism. Thus, following such a view, the supporters of ongoing European integration cannot be considered as true federalists (Héraud 1959: 3). Héraud would develop, in the Sixties, an approach that he defined as "ethno-federalism" which sought to reunify Europe, starting with ethnic communities or regions created through referendums destined to reunify peoples with the same ethnic roots (for example, SouthTirol people with Austrian people). ${ }^{\mathrm{XI}}$ These regions/communities had to be the centre of a new process of integration, opposed to the process developing under the control of sovereign states. From Héraud's stand point, these were simply the result of violence and diplomacy, distant from the people's will. Thus, he stood for a "people's federation" rather than a "state's federation", with the idea of destroying national-sovereignty through a radical fragmentation of power that would be recomposed at European level (as a European sovereignty) following the subsidiarity principle (Héraud 1963; 1968; 1973). Héraud's ideas achieved a certain success in the ideological landscape of the time, that in any case presented other similar tendencies. If we consider the Seventies review "Junges Forum" that was directed by Henning Eichberg, a German theoretician of ethno-pluralism, or the French review entitled "Nouvelle École" - the Nouvelle Droite magazine - you find, alongside several articles by Héraud (also in the comité de patronage of Nouvelle École in 1971), several criticisms of the liberal and "antifederal" EEC. Similar ideas were published by "Intereg" - (Internationales Institut für Nationalitätenrecht und Regionalismus - an institute advocating for the rights of ethnic groups and regionalism), a Bavarian think tank founded by CSU through the Bayerische Landeszentrale für Politische Bildungsarbeit; publications such as the Review "Europa Ethnica" (Ruge 2003, 2015: 90-104). These ideas gained ground in the Mittle-European and Northern European right-wing, post-fascist, regionalist, and ecologist landscape, becoming part of the political programme of parties such as "La Lega Nord" in Italy, the FPÖ in Austria, the "Vlams Bloock" in Netherland, etc (Luverà 1996a; 1996b; 
1999). ${ }^{X I I}$ All these movement shared, especially between the 80 s and the 90 s, a critical idea of modern nation-state sovereignty founded on the individual as the centre of the political pact, a radical form of Euroscepticism, refusal of liberalism and "marketism", and a positive view of a form of ethno-federalism for the whole of Europe. At this point, it is interesting to briefly consider two approaches that could be considered representative of the two main evolutions of such a form of "Eurosceptic federalism" in the post-Maastricht Debate: communitarian (as in the case of Alain de Benoist) and libertarian (such as Gianfranco Miglio).

\section{3.}

Alain de Benoist is a French philosopher, author of dozens of books, considered the main exponent of the "Nouvelle Droite", and one of the most controversial and debated figures on the European intellectual landscape. Coming from the extreme right environment - with which he still retains a certain dialogue and sentiment - he decided during the Seventies to move beyond right and left, theorising an original form of communitarian federalism which opposes nationalism, modern state sovereignty, capitalism, globalisation and liberalism. ${ }^{\text {XII }}$ In the opinion of de Benoist - who has always remembered his European roots and stands for European federalism as the political solution for the old continent - the EU, far from being an answer to the problems of our time, is in itself one of the problems. The reasons are to be found in its history that has focused on market integration, ${ }^{\mathrm{XIV}}$ and the refusal to centre the debate on political and cultural integration. The result, for Benoist, is that it misses the meaning of integration and creates just one void and centralised bureaucratic system. Such a system takes only the worst from modern politics, ${ }^{\mathrm{XV}}$ achieving the opposite of the "integral federalism" model which, following the thought of Althusius (de Benoist 2000: 25-58), would begin from the lowest communitarian levels in order to build a continental frame of symbiotic communities. ${ }^{\mathrm{XVI}}$ From this point of view, the EU is simply the negation of all federalism, and the achievement of a form of Jacobinism:

“La dénonciation rituelle par les souverainistes de l'Europe de Bruxelles comme une «Europe fédérale» ne doit donc pas faire illusion: par sa tendance à s'attribuer autoritairement toutes les compétences, elle 
se construit au contraire sur un modèle très largement jacobin. Loin d'être «fédérale», elle est même jacobine à l'extrême, puisqu'elle conjugue autoritarisme punitif, centralisme et opacité" (de Benoist 2014 a).

Such a system is the logical offspring of functionalism, and progresses directly towards its unconscious self-destruction. Far from destroying the centralistic logic of the nationstate it just exasperates it, causing a reaction within the member states that can bring about a rupture of the system in a condition of accentuated nationalism, as the case of Brexit shows. After the UK referendum, according to de Benoist, the ruling elite governing the European Union does not want to call into question the ongoing integration path:

\footnotetext{
"the only lesson that they took from this vote is that is necessary to do the utmost to avoid people expressing themselves. Who said that madness consisted of always doing the same thing hoping to obtain different results? Considering that the same causes provoked the same effects, they will continue to pour petrol on a fire which will up consuming everything” (de Benoist 2016: 6).
}

As we saw, de Benoist considers this path to be just the opposite of that towards true European federalism. Far from being just a reflection of the last few years, such criticism of the EU has been developed by de Benoist since the 90s, and he has been interested in

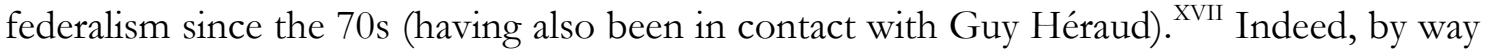
of confirmation, in 2012 he reprinted in English - with Charles Champentier - the "Manifesto for the European Renaissance" that was originally published in 1999 in the "Éléments" review. This "Manifesto" sums up his ideas about Europe and European Civilisation. An explicit "position" of the book is entitled "Against Jacobinism; for a Federal Europe" (Champentier and de Benoist 2012: 38). Such opposition towards a centralised state - thoughts on the model of the modern nation-state - found (and still finds) a paradoxical common ground with libertarians that contested the EU as incapable of breaking the hated logic of sovereignty.

4.

For that reason it is interesting to focus on the thoughts of Gianfranco Miglio, an Italian historian and political scientist who, for many years, studied the German classics 
concerning the theory and history of the state. ${ }^{\mathrm{XVIII}}$ During the 80 s and $90 \mathrm{~s}$ he developed a vision of federalism that, founded on the Mittle-Europa experience, aimed to be a radical alternative to the modern state model. In his view the epoch of the huge, united, modern, nation-state reached its apogee with the growing scientific criticism of the myth of nation and the substantial impossibility for the united-state to satisfy the different exigencies of millions of citizens. The same success of the market economy - and of the private over the public sphere - accelerated the process and transformed the old state into an obsolete reality (Miglio 2016a: 59-64). It is important to note that contrary to de Benoist - and several of the previously quoted authors - he was not a critic of capitalism and market economy, but considered them as being intimately connected to the logic of his "neofederalism". XIX Precisely for that reason he believed socialism to be the opposite of federalism, defining socialism as essentially intertwined with the modern, centralised, and unitary state (Miglio 2016b: 69-70). At the same time, he was attracted by the political experience of the "Lega Nord" that he considered a revolutionary force able to open the perspective of a Europe of regions beyond the nation-state experience. ${ }^{\mathrm{xx}}$ During the $90 \mathrm{~s}$ he developed a radical critique of the EU that was founded on three fundamental aspects: 1) the EU did not break with the nation-states, considering that "political fractions inside the nation states were firmly decided to conserve their privileges"; 2) the ruling perspective of European integration was that of "L'Europa di Bruxelles" or of a European supernation-state that applied the worst aspect of nation-state bureaucracy; and 3) the EU moved towards paralysis because the reunification of Germany broke up the old balance in the European nation-state, introducing an hegemonic actor that pushed other powers (like America) to adopt a suspicious and antagonistic attitude towards the process of European integration (Miglio 2016c: 183-186). Against such nation-states in Europe, Miglio proposed a "Europa delle Regioni", or a union founded on macro-economic regions and cities connected each to another within a network of federal relations (Miglio 2016d: 186-187). In this "neo-federal" union:

\footnotetext{
"le istituzioni europee (e dunque le leggi che le regoleranno) dovranno essere il risultato di accordi negoziati, piuttosto che di diktat di organi sovrani ... come ogni sistema federale la comunità europea sarà composta di minoranze ... La loro protezione implica che nei loro riguardi non si potrà mai invocare l'ipotetico diritto di maggioranza ..."
} 
In his opinion, majority rule could only be used if all attempts at negotiation failed, and then only through using a principle of qualified majority. Furthermore:

"Tutte le decisioni importanti dovranno inoltre essere accompagnate da una clausola di non partecipazione, per preservare il diritto della comunità a dire "no"”, (Miglio 2016e: 191-192).

According to this understanding, true federalism was where the territorial units that constitute the federation directly express government as a form of direction (following the Swiss example). Consequently, the kind of European Federalism directly inspired by Alexandre Hamilton (as that of Altiero Spinelli) was a false federalism, secretly influenced by the passion for unity that informed the whole history of the modern state. ${ }^{\mathrm{XXI}} \mathrm{A}$ federal state, according to the "profesùr", was always an "ossimoro" that tried to bring together two models of politics that were totally opposed. In this sense he criticised the EU's damaging attitudes in its alternative response to unitary logic of the nation-state (at the level of Brussels for some politics, and in its inter-governmental attitude for the others); consequently Miglio remained a convinced supporter of constitutional pluralism as being the fundamental feature of federalism.

5.

What do these different "Eurosceptic federalist" approaches have in common? They fundamentally reject all the traditions of the European sovereign state, as a history of centralism and violence, contest the possibility of a Federal State - which in their view is not a true federation - and eschew any integration that will, in any way, keep alive the existing nation-state. Concisely, they refused the path of a "European rescue of [the] nation-state" (Milward 1992) or a confederative approach that would allow the nation-state to survive by merely sharing some power in particular spheres. They also question the other, more common, federalist approach -which the EU considers as "better than nothing" - about the nature of their federalism, and the possible conception of other solutions to the issue of sovereignty (different from the Althusian xxII or just "a-sovereign" one ${ }^{\mathrm{XXIII}}$ ) and the consequences that such a reflection would eventually entail on their 
evaluation of EU. This stand enabled them to see things from another perspective that, nowadays, remains "merely" theoretic. In effect, in the light of this conceptual weakness in contemporary political debate on the future of Europe, it is also possible to verify how the birth of the European integration process had substantially unified - with notable exceptions - the field of Euroscepticism with that of nationalism, confirming a harsh defeat for those federalist alternatives that even in the 90 s could count on the support of relevant parties/foundations. So, in what way is it useful to be reminded of such an approach?

6.

First, it is relevant to better define the complexity, plurality, and non-homogeneity of the history of both "European federalism" and "Euroscepticism", allowing us to also better evaluate the particularity of the current epoch compared, just as an example, to that of the $80 \mathrm{~s}$ and the 90s. Second, it could be useful to help formulate some relevant questions, which will allow us to better define some main issues that will shape the European political landscape. What is the relationship between the EU, federalism, and the modern state? Must the EU make a choice between one or the other or does it just have to find a new path to allow federalism and the modern state to become entangled with one another? Is it possible to manage a single continental capitalist economy without any form of State mechanism around it? And can any possible continental and federal democracy survive through a crisis without any form of state that is able to organise it? And last - but not least - is it true that in the long run European functional integration, as has been experimented with until now, can bring about, as a reaction, a return to nationalism (and consequent disintegration, Zielonka 2014) ${ }^{\mathrm{XxIV}}$ ? Considering the fundamental challenges that will be faced by the EU over the next three years - starting with Brexit and culminating with a probable discussion about a new European treaty -underestimating the political relevance of these questions is not a viable option. The same "pro-EU" federalists will benefit from a renewed, and serious confrontation, with these issues in order to find advanced and coherent solutions to problems that, in any case, will be decisive for the future of Europe. ${ }^{\mathrm{xxv}}$

\footnotetext{
* Dr. Tommaso Visone is Adjunct Professor in Political Thought for Colonization and Decolonization at SapienzaUniversità di Roma and Research Fellow in the History of Economic Thought at Università degli studi di Roma
} 
Tre. From 2013 to 2017 he has been Research Fellow in the History of Political Thought at Scuola Superiore Sant'Anna of Pisa. He is co-editor of the review "Stati Uniti d'Europa" and of the series "Teoria e ricerca sociale e politica", Altravista (Pavia). In 2013 he obtained his PhD in Political Sciences at the University of "Roma Tre". As a researcher, analyst and leader, he has been involved in activities of different study centres, scientific journals and magazines such as CSF (Centre for Studies on Federalism); A.R.E.L.A. (Association for the Euro-Mediterranean and Latin-American research), Cesue (Centre for Studies, Research and Education on European Union), "EuroStudium", "Sintesi Dialettica", "Mezzogiorno Europa", "Critica Liberale", "Mondoperaio", etc. As scholar he has been invited to participate in seminars and research projects with Université Paris I Panthéon-Sorbonne; University of Cambridge; The University of Hong Kong; Universitatea din București and Université de Savoie. Among his latest publications figure L'Idea d'Europa nell'età delle ideologie (1929-1939). Il dibattito francese e italiano, Chemin de $\operatorname{Tr} @$ verse, Paris, 2012; Categorie, Significati e Contesti. Una questione rilevante per gli studi sull'uomo, Mimesis, Milano, 2014 (with Andrea Spreafico) and L'Europa oltre l'Europa. Metamorfosi di un'idea nel dibattito degli anni trenta (1929-1939), ETS, Pisa, 2015.

I The word "Euroscepticism" means such a discourse and/or action that promotes "opposition and doubt [in] to the process of European integration". See Taggart (1998: 365). In the particular perspective of this paper - focused on a "principle opposition" to a particular path of European integration, developing historically since 1951 - the only possible "Euroscepticism" is that which Paul Taggart and Aleks Szczerbiak called "hard Euroscepticism". See Taggart and Szczerbiak (2002: 7). For criticisms concerning the concept of "Euroscepticism" and its uses see Pasquinucci and Verzichelli (2016).

II Marine Le Pen, Speech of the 19th November 2011, quoted in Lanathoua (2012: 1). See also the criticism developed by Marine Le Pen towards the perspective of European federalism in Le Pen (2012: 56).

III In this paper the expression "European federalism" is intended to mean any political perspective that strives for the creation of a federation capable of covering the European space. From this broad and analytic point of view, it matters not which kind of definition of federalism is the original or theoretically correct or which definition of Europe is, spatially or philosophically, "the right one". What matters here is the joint and related discursive use - with a precise political aim - of the words federalism/federation and Europe in a particular context that is one of the political debates of $\mathrm{XX}^{\text {th }}$ and XXIst century Western Europe. On the history of federalist thought, see Kincaid (2011); Ward and Ward (2009); Levi (2008); Malandrino (1998).

IV "By pooling basic production and by instituting a new High Authority, whose decisions will bind France, Germany and other member countries, this proposal will lead to the realization of the first concrete foundation of a European federation indispensable to the preservation of peace". Schuman Declaration, 9 May 1950.

$\mathrm{V}$ Regarding the concrete impact of such federalism on the process of European Integration, see Burgess (2006).

VI As a paradoxical and border case it is interesting to consider the same Union of European Federalist - Uef - in a peculiar moment of its history (1957-1962). During this period the Uef was split into two parts: ones, consisting of the Germans, Dutch and a part of the French federalist movement (European Federalist Action, 1956), critically supported the perspective of a functional integration opened with the Treaties of Rome, while the others - the majority - opposed this, considering the Common Market as a "step back" (Constantinescu 1959: 1) towards the creation of a true supranational federation. This majority finally transformed the Uef into the "Supranational Federalist Movement" (1959), which was engaged in the antifunctionalist campaign concerning the "Congress of European People". See Pistone (2008: 131-154). In the same period, Altiero Spinelli wrote a second federalist manifesto (1957) in which he labelled as "false European solutions" those proposed by functionalism and Europeanism, affirming that all these solutions "expressed the secret dream of the exploiters/profiters of the national sovereignties and of their political representatives" (Spinelli 1957: 57-65).

VII Drieu La Rochelle (1934: 17). On the life of Pierre Drieu La Rochelle, see Cantier (2011). On his political thought, see Rocca (2000). On the connection of such thoughts with his novels, see the interesting interpretation of Solé Castells (2004), and the reconstruction by Bruneau (2011).

VIII See Drieu La Rochelle (1973: 189-190; 217-218). In 1939 he observed in his "Journal," "c'est l'agonie de l'Europe: à Genève on voit la bassesse de cette Europe des petites nations... Et si Genève a échoué, l'hégémonie anglo-française, il faut bien qu'une autre s'offre. Il faut bien faire les Etats-Unis d'Europe par la violence" (See Drieu La Rochelle, 1992: 80).

Ix About the "Ordre Nouveau" perspective, see also Roy (1999), Hellmann (2002), and Visone (2012: 181196). 
$\mathrm{x}$ Who was also candidate for the European Federalist Party (against the candidature of Jean-Claude Sebag, representative of the European Federalist Movement that was in favour of strengthening the supranational aspects of EEC), in the French Presidential Elections of 1974 (with a regionalist programme for France). During these elections he defined "federalism as a form of anti-centralism, as an auto-managing socialism", as outlined in this recorded declaration now available on YouTube http://www.ina.fr/video/CAF94054982/guy-heraud-video.html .

$\mathrm{XI}$ In his opinion, a commission of ethnologists, historians, geographers, and linguists had to determine the territory in order to consult such a referendum.

XII In 1993 Bossi, Haider and Héraud appeared as authors in the same book dedicated to "etno-federalism" (Hatzenbichler - Mòlzer 1993).

XIII On his biography and thought, see Andriola (2014); Weber (2011); Sissa (2010); Böhm (2008); Stara (2007); Dard (2006: 125-135); Preve (2006); Germinaio (2002); Taguieff (1994).

XIV For such a topic, see also the recent writing of de Benoist (2015).

$\mathrm{XV}$ In fact, it is his view that the EU, even if centralised for economic policy, cannot undertake any kind of foreign policy because of the role of nation states inside the same EU: "La politique étrangère est le revers de la souveraineté nationale. L'Union européenne ne constituant pas un corps politique, il ne peut évidemment pas y avoir de politique étrangère commune, mais tout au plus un agrégat conjoncturel de diplomaties nationales assorti d'une politique «extérieure» dérivée des compétences «communautaires». Que ce soit à propos de l'intervention américaine en Irak, de la guerre en Libye, au Mali ou en Syrie, que ce soit à propos de la Russie on du Proche-Orient, de la Palestine, du Kosovo on plus récemment de la Crimée, les Européens ont toujours été incapables d'adopter une position commune, la majorité d'entre eux se contentant de s'aligner sur les positions américaines. Ne se percevant pas d'intérêts communs, ils ne sauraient avoir non plus de volonté commune ou de stratégie commune" (de Benoist 2014a).

XVI From this point of view, de Benoist is a harsh critic of Bodinian and Hobbesian sovereignty (or an exclusive sovereignty) and in favour of a divided, Althusian sovereignty (See de Benoist 2002). On the issue of sovereignty in connection with his criticism of the EU, see also de Benoist (2014b).

XVII During the 90s, de Benoist also conceived - as d'Ors did in the 30s - a federal model for Europe as an Imperial model or a reunion of diversities around an idea, a principle (See de Benoist 1995: 173-175). On the relationship between Pierre Drieu La Rochelle's thought, fascism, ethno-federalism, and Alain de Benoist's perspective, see Spektorowski (2016: 115-138).

XVIII Regarding his biography and thought, see Ferrari (1993); Campi (1996); Palano (2005: 289-450); Di Capua (2006); Romano (2010); Malandrino (2012: 90-99); Bianchi and Petroni (2013).

XIX “... per capire il cambiamento di fine secolo, dunque, è necessario comprendere la vocażione al contratto, al pluralismo e al federalismo che nasce dall'impossibilità di gestire altrimenti i bisogni dei governati. Questi infatti sono talmente vari che possono essere soddisfatti solo nel libero mercato" (Miglio, Barbera 1997: 31).

xx He was also a senator with the Lega Nord from 1992 to 1994: when it broke up, passing to the "gruppo misto".

XXI In several publications, Miglio defined American federalism as a "degenerate federalism" and the German one as a "false federalism" (See Malandrino 2012: 91). On the criticism to Hamilton and the idea that the American "anti-federalists" were "the true" federalists, see also Bassani (2009).

XXII "... Althusius divides the public association into particular and universal. The particular, in turn, is divided into the city and the province, and the universal is identified as the commonwealth ('res-publica'), or realm ('regnum'). The particular association does not possess sovereignty, while the universal does. It should be noted, however, that the city of Venice, because it possessed sovereignty, had the status of a commonwealth. Furthermore, while a city is composed of families and collegia, the province is formed of various kinds of local community ranging from the rural hamlet to the metropolis, and the commonwealth is constituted of provinces and such cities as have the rights and responsibilities of provinces in the assemblies of the realm (...) The commonwealth, as previously noted, differs from the city and province in that it alone possesses sovereignty. This is to say, only the commonwealth recognizes no human person or association as superior to itself. But where in the commonwealth does this sovereignty reside? Jean Bodin, to whom Althusius was highly indebted for so many of the characteristics of his political system, attributed it to the ruler. Althusius disagreed. His position, which followed consistently upon the principles he had already elaborated in smaller associations, was that sovereignty is the symbiotic life of the commonwealth taking form in the 'jus regni', or in the fundamental right or law of the realm. Since the commonwealth is composed not of individual persons but of cities and provinces, it is to them when joined together in communicating things, services, and right that sovereignty belongs. Therefore, it resides in the organized body of the 
commonwealth, which is to say in the symbiotic processes thereof. This organized body was also known to Althusius as the people" (Carney 1965: XVII-XX). On the thought of Althusius, see also Malandrino (2016). XXIII That was the opinion of Carl J. Friedrich who wrote "No Sovereign can exist in a federal order system; autonomy and sovereignty exclude each other in such a political order ... No one has the last world" (Friedrich 1968: 7). A different solution was that of James Wilson who argued in the Ratifying Convention of Pennsylvania (1787) that "the supreme power ... resides in the PEOPLE, as the fountain of government ... They can delegate it in such proportions ... as they think proper ... to the governments" and "to the government of the United States" (See Levi 2013: 25-26).

XXIV Phenomenon which can entail the direct disintegration of the Union or the disintegration of member states with indirect - but serious - effects on the nature and the functioning of the EU. It is no accident that - to give an example of the new "Europeanist nationalisms" - Catalan independentism considers EU fullmembership as one of its fundamental targets.

$\mathrm{xxV}$ From this point of view, it is interesting to read the reflection of a pro-EU federalist scholar, contained in Fabbrini (2017).

\section{References}

- Andriola Matteo Luca, 2014, La Nuova destra in Europa. Il populismo e il pensiero di Alain de Benoist, Edizioni Paginauno, Milano.

- Bassani Luigi Marco, 2009, Dalla rivoluzione alla guerra civile. Federalismo e Stato moderno in America 17761865, Rubbettino, Soveria Mannelli.

- Bianchi Davide Gianluca and Petroni Giorgio (eds), 2013, Attualità del pensiero e dellimpegno politico di Gianfranco Miglio: atti del convegno: Elementi di attualità del pensiero e dell'impegno di Gianfranco Miglio, Biblioteca del Senato della Repubblica “Giovanni Spadolini”, Roma, 24 gennaio 2012, Le Monnier, Firenze.

- Böhm Michael, 2008, Alain de Benoist und die Nouvelle Droite. Ein Beitrag zur Ideengeschichte im 20. Jabrbundert, Lit, Berlin.

- $\quad$ Bruneau Jean-Baptiste, 2011, Le cas Drieu. Drieu la Rochelle entre écriture et engagements. Débats, représentations et interprétations de 1917 à nos jours, Eurédit, Paris.

- Burgess Michael, 2006, Federalism and European Union. Political Ideas, influences and strategies in European Community, 1972-1987, Routledge, London.

- Campi Alessandro, 1996, Schmitt, Freund, Miglio. Figure e temi del realismo politico europeo, La Roccia di Erec, Firenze.

- $\quad$ Cantier Jacques, 2011, Pierre Drieu la Rochelle, éditions Perrin, Paris.

- Carney Frederic S., 1965, Translator's Introduction in, Johannes Althusius, The Politics of Johannes Althusius, Eyre and Spottiswood, London.

- Constantinescu Leontin, 1959, 'La Ceca e I limiti del funzionalismo’, Popolo Europeo, no. 14, March.

- Dard Olivier, 2006, 'La Nouvelle Droite et la société de la consommation', Vingtième siècle. Revue d'histoire, 3, no. 91: 125-135.

- de Benoist Alain, 1995, L'impero interiore. Mito, autorità, potere nell'Europa moderna e contemporanea, Ponte alle Grazie, Firenze, 1995.

- de Benoist Alain, 2000, 'The first federalist: Johannes Althusius', Telos: Critical Theory of the Contemporary, no. 118: 25-59.

- de Benoist Alain, 2002, Critique Théoriques, Editions l'Age d'homme, Lausanne.

- de Benoist Alain and Champetier Charles, 2012, Manifesto for a European Renaissance, Arktos, London.

- de Benoist Alain, 2014a, 'Europe marché ou Europe puissance', Blogéléments. Pour la civilisation européenne, 26 April, http://blogelements.typepad.fr/blog/2014/04/alain-de-benoist-europe-march\%C3\%A9ou-europe-puissance.html .

- $\quad$ de Benoist Alain, 2014b, La fine della sovranità. Come la dittatura del denaro toglie potere ai popoli, Arianna Editrice, Bologna. 
- de Benoist Alain, 2015, Le traité transatlantique et autres menaces, Éditions Pierre-Guillaume de Roux, Paris.

- de Benoist Alain, 2016, 'Brexit: verso un effetto domino in Europa?', Diorama Letterario, no. 332, JulyAugust: 6.

- Di Capua Giovanni, 2006, Gianfranco Miglio, scienziato impolitico, Rubbettino, Soveria Mannelli.

- d'Ors Eugeni, 1920, 'Dialètica y principio federativo', Las Noticias, 25-IV: 1.

- Drieu La Rochelle Pierre, 1934, 'Enquête sur le rajeunissement de la France', La Grand Revue, n.3, March: 14-17.

- Drieu La Rochelle Pierre, 1973, Socialismo Fascista, Ege, Roma (original edition 1934, Socialisme Fasciste, Gallimard, Paris).

- $\quad$ Drieu La Rochelle Pierre, 1992, Journal 1939-1945, Gallimard, Paris.

- $\quad$ Fabbrini Sergio, 2017, Sdoppiamento. Una prospettiva nuova per l'Europa, Laterza, Roma.

- $\quad$ Ferrari Giorgio, 1993, Gianfranco Miglio. Storia di un giacobino nordista, Liber internazionale, Milano.

- $\quad$ Friedrich Carl J., 1968, Trends of federalism in theory and practice, Praeger, New York-Washington-London.

- Germinaio Francesco, 2002, La destra degli dei: Alain de Benoist e la cultura politica della Nouvelle droite, Bollati Boringhieri, Torino.

- Glady Michel (Marc Alexandre), 1934, 'A hauteur d'homme (des frontières au fédéralisme)', Ordre Nowveau, no. 15, November: 8-22.

- Hatzenbichler Jünger and Mòlzer Andreas (eds), 1993, Europa der Regionen, Stocker, Gratz.

- Hellmann John, 2002, The Communitarian Third Way: Alexandre Marc's Ordre Nouveau 1930-2000, McGillQueen's University Press, Montreal \& Kingston, London, Ithaca.

- Héraud Guy, 1959, 'Federalismo e confederalismo', Il Popolo Europeo, no. 13, February: 3.

- $\quad$ Héraud Guy, 1963, L'Europe des ethnies, Presses d'Europe, Nice.

- Héraud Guy, 1968, Les principes du fédéralisme et la fédération européenne, Presses d'Europe, Nice.

- Héraud Guy, 1973, Contre les États les Régions d'Europe, Presses d'Europe, Nice.

- $\quad$ Kincaid John (ed), 2011, Federalism, Volume I, Sage Publications, London.

- Lanathoua Mathilde, 2012, 'Marine Le Pen et la deconstruction européenne', Terra Nova, Note, 5 March: 1-17.

- $\quad$ Le Pen Marine, 2012, Pour que vive la France, Grancher, Paris.

- $\quad$ Levi Lucio, 2008, Federalist Thinking, University Press of America, Lanham.

- Levi Lucio, 2013, 'The Invention of Federalism, in Immanuel Kant and Alexandre Hamilton, the Founders of Federalism', in Castaldi Roberto (ed), Immanuel Kant and Alexander Hamilton, the Founders of Federalism: A Political Theory for Our Time, Peter Lang, Bruxelles, 15-42.

- Luverà Bruno, 1996a, 'L’internazionale regionalista fra maschera e volto', LiMes. Rivista italiana di geopolitica, no. 3: 35-58.

- Luverà Bruno, 1996b, 'Prospettive e rischi del neoregionalismo europeo', in Il Mulino. Rivista di cultura e politica, no. 1: 136-148.

- Luverà Bruno, 1999, I confini dell'odio. Il nazionalismo etnico e la nuova destra europea, Editori Riuniti, Roma.

- Malandrino Corrado, 1998, Federalismo. Storia, Idee, Modelli, Carocci, Roma.

- Malandrino Corrado, 2012, Democrazia e federalismo nell'Italia Unita, Claudiana, Torino.

- Malandrino Corrado, 2016, Johannes Althusius (1563-1638): teoria e prassi di un ordine politico e civile riformato nella prima modernità, Claudiana, Torino.

- $\quad$ Martínez Carrasco Alejandro, 2014, D’Ors y Ortega frente a frente, Dykinson, Madrid.

- Miglio Gianfranco and Barbera Augusto, 1997, Federalismo e secessione: un dialogo, Mondadori, Milano.

- Miglio Gianfranco, 2016, 'Ma è nel federalismo che emerge la modernità' (1990), in Miglio Gianfranco, Scritti Politici, (Bassani Luigi Marco ed), Pagine, Roma, 59-64.

- Miglio Gianfranco, 2016, 'Io e la Sinistra' (1992), in Miglio Gianfranco, Scritti Politici, (Bassani Luigi Marco ed), Pagine, Roma, 69-84.

- Miglio Gianfranco, 2016, 'L’Europa di Bruxelles è un relitto' (1993) in Miglio Gianfranco, Scritti Politici, (Bassani Luigi Marco ed), Pagine, Roma, 183-189. 
- Miglio Gianfranco, 2016, 'Evitiamo di sacrificare la diversità europea sull'altare dell'integrazione!' (1996), in Miglio Gianfranco, Scritti Politici, (Bassani Luigi Marco ed), Pagine, Roma, 190-193.

- Milward Alan S., 1992, The European Rescue of the Nation-State, Routledge, London.

- Palano Damiano, 2005, Il cristallo dell'obbligazione politica. La scienza del potere di Gianfranco Miglio, in Palano Damiano, Geometrie del potere: materiali per una storia della scienza politica in Italia, Vita e Pensiero, Milano, 289-450.

- $\quad$ Pasquinucci Daniele e Verzichelli Luca (eds), 2016, Contro l'Europa? Diversi scetticismi verso l'integrazione europea, Il Mulino, Bologna.

- $\quad$ Pistone Sergio, 2008, L’Unione dei Federalisti Europei, Guida, Napoli.

- $\quad$ Preve Costanzo, 2006, Il paradosso de Benoist. Un confronto politico e filosofico, Settimo Sigillo, Roma.

- $\quad$ Rocca Daniele, 2000, Drieu La Rochelle : aristocrazia, eurofascismo e stalinismo, Stylos, Aosta.

- $\quad$ Romano Luca (ed), 2010, Il pensiero federalista di Gianfranco Miglio: una lezione da ricordare. Atti del Convegno di studi, Venezia 17 aprile 2009, Sala del Piovego di Palazzo Ducale, Consiglio regionale del Veneto, Venezia.

- $\quad$ Roy Christian, 1999, Alexandre Marc et la Jeune Europe (1904-1934). L'Ordre Nouveau aux origines du personnalisme, Presses d'Europe, Nice.

- Ruge Undine, 2003, Die Erfindung des "Europa der Regionen". Kritische Ideen geschichte eines konservatives Konzept, Campus Verlag, Frakfurt.

- $\quad$ Ruge Undine, 2015, "The Call for a New European Order: Origins and Variants of the Ant-Liberal Concept of the "Europa of the Regions", in Gosewinkel Dieter (ed), Anti-liberal Europe: a neglected History of Europeanization, Berghahn Books, New York, 90-104.

- Sissa Stefano, 2010, Pensare la politica controcorrente. Alain de Benoist oltre l'opposizione destra-sinistra, Arianna Editrice, Bologna.

- Solé Castells Cristina, 2004, La obra novelistica de Pierre Drieu La Rochelle. Una cruzada en pos de la trascendencia, Edicions de la Universitat de Lleida, Lleida.

- Spektorowski Alberto, 2016, 'Fascism and Post-National Europe: Drieu la Rochelle and Alain de Benoist', Theory, Culture and Society, XXXIII(1): 115-138.

- $\quad$ Spinelli Altiero, 1957, Manifesto dei federalisti europei, Guanda, Parma.

- Stara Pietro, 2007, La comunità escludente: La Nuova Destra tra piccole patrie e Europa nazione, Zero in Condotta, Milano.

- Taggart Paul, 1998, 'A Touchstone of Dissent: Euroscepticism in Contemporary Western European Party Systems’, European Journal of Political Research, XXXIII(3): 363-388.

- Taggart Paul and Szczerbiak Aleks, 2002, 'The Party Politics of Euroscepticism in EU Member and Candidate States', SEI Working Paper, No. 51, 'Opposing Europe Research Network' Working Paper, No. 6: 1-45.

- Taguieff Pierre-André, 1994, Sur la Nouvelle Droite. Jalons d'une analyse critique, Descartes \& Cie, Paris.

- Visone Tommaso, 2012, L’idea d'Europa nell'età delle ideologie (1929-1939). Il dibattito francese e tedesco, ChemindeTr@verse, Paris.

- Visone Tommaso, 2014, 'La réaction au cosmopolitisme dans les années trente. L'idée d'Europe chez Asvero Gravelli, Carl Schmitt et Drieu la Rochelle', in Mattiato Emmanuel, Lucarelli Massimo and Lemke Ute (eds), Cosmopolitisme et réaction dans l'entre-deux-guerres dans le triangle France-Allemagne-Italie, Presses de l'Université de Savoie, Chambéry, 113-142.

- Visone Tommaso, 2015, L'Europa oltre l'Europa. Metamorfosi di un'idea nel dibattito degli anni trenta (1929. 1939), ETS, Pisa.

- Ward Ann and Ward Lee, (eds), 2009, The Ashgate Research Companion to Federalism, Ashgate Research Companion, Ashgate Publishing Limited, Farnham.

- Weber Ines, 2011, Die politische Theorie von Alain de Benoist, Tectum-Verlag, Marburg.

- $\quad$ Zielonka Jan, 2014, Is the EU doomed ?, Polity Press, Cambridge. 